\title{
P21-Associated ncRNA DNA Damage-Activated Expression in Bladder Cancer
}

\author{
Exprese ncRNA spojené s P21 aktivovaná poškozením DNA \\ u karcinomu močového měchýře
}

\author{
Abdolmaleki F. ${ }^{1}$, Ghafouri-Fard S. ${ }^{1}$, Taheri M. ${ }^{2}$, Omrani M. D. ${ }^{3}$ \\ 'Department of Medical Genetics, Shahid Beheshti University of Medical Sciences, Tehran, Iran \\ 2 Urogenital Stem Cell Research Center, Shahid Beheshti University of Medical Sciences, Tehran, Iran \\ ${ }^{3}$ Urology and Nephrology Research Center, Shahid Beheshti University of Medical Sciences, Tehran, Iran
}

\begin{abstract}
Summary
Background: Long non-coding RNAs (IncRNA) have recently been the focus of attention of cancer researchers due to their diverse roles in the carcinogenesis process. These transcripts regulate critical steps in the normal cellular processes, so dysregulation of their expression participate in the pathogenesis of several cancers. P21-associated ncRNA DNA damage activated (PANDA) has a special situation in this regard due to its adjacency to the CDKN1A locus. It is involved in the regulation of DNA damage response as well as cell senescence and proliferation. Material and methods: In the current study, we assessed the expression of this IncRNA in bladder cancer tissue, adjacent non-cancerous tissues (ANCTs) and normal bladder samples by means of quantitative real time PCR method. Results: No significant difference has been detected in PANDA expression either between tumour tissue and ANCTs (expression ratio 1.75, $\mathrm{P}=0.11$ ) or between tumour tissue and normal tissues (expression ratio 2.72, $\mathrm{P}=0.57$ ). The expression level of this IncRNA was not associated with any of the demographic or clinical data of patients such as tumor grade or recurrence or cancer-associated risk factors such as cigarette smoking or opium addiction. Conclusion: Consequently, the current study implies that PANDA is not involved in the pathogenesis of bladder cancer. Assessment of expression of other IncRNAs would help in identification of biomarkers for this cancer.
\end{abstract}

Key words

P21-associated ncRNA - DNA damage-activated - PANDA - RNA - long non-coding - urinary bladder neoplasms

\section{Souhrn}

Úvod: Dlouhé nekódující ribonukleové kyseliny (long non-coding ribonucleic acids - IncRNA) jsou v poslední době vzhledem ke své úloze v procesu karcinogeneze předmětem zkoumání vědců zabývajících se nádory. Tyto transkripty regulují kritické kroky v normálních buněčných procesech, takže dysregulace jejich exprese se účastní patogeneze karcinomů. Z důvodu své blízkosti k lokusu CDKN1A má ncRNA spojená s P21 aktivovaná poškozením DNA (P21-associated ncRNA DNA damage activated - PANDA) v tomto ohledu zvláštní pozici. Podílí se na regulaci reakce na poškození DNA, stárnutí buněk a proliferace. Materiály a metody: $\mathrm{V}$ této studii jsme metodou kvantitativní polymerázové řetězové reakce hodnotili expresi této IncRNA ve tkáních karcinomu močového měchýre, sousedních nerakovinných tkání (adjacent non-cancerous tissues - ANCT) a v normálních vzorcích močového měchýre. Výsledky: Nebyl detekován žádný významný rozdíl v expresi PANDA, a to ani mezi nádorovými tkáněmi a ANCT (poměr exprese $=1,75 ; \mathrm{p}=0,11$ ) nebo mezi nádorovými tkáněmi a normálními tkáněmi (poměr exprese $=2,72 ; p=0,57$ ). Úroveň exprese této IncRNA nebyla spojena s žádnými demografickými ani klinickými údaji o pacientech, jako je grade nádoru nebo recidiva, ani s rizikovými faktory souvisejícími s rakovinou, mezi něž patří např. kouření cigaret nebo závislost na opiu. Závěr: Tato studie tedy naznačuje, že PANDA není zapojena do patogeneze karcinomu močového měchýře. Hodnocení exprese jiných IncRNA by mohlo pomoci při identifikaci biomarkerů pro tyto karcinomy.
The current study was supported by a grant from the Shahid Beheshti University of Medical Sciences.

Tato studie byla podpořena grantem univerzity Shahid Beheshti University of Medical Sciences.

The authors declare they have no potential conflicts of interest concerning drugs, products, or services used in the study.

Autoři deklarují, že $v$ souvislosti s predmětem studie nemají žádné komerční zájmy.

The Editorial Board declares that the manuscript met the ICMJE recommendation for biomedical papers.

Redakční rada potvrzuje, že rukopis práce splnil ICMJE kritéria pro publikace zasílané do biomedicínských časopisů.

\section{$\equiv{ }^{\circ}$}

Mir Davood Omrani, M.D.

Urology and Nephrology Research

Center

Shahid Beheshti University

of Medical Sciences

9th Boostan St, No. 103

Tehran, Iran

e-mail: davood_omrani@yahoo.co.uk

Submitted/Obdrženo: 27. 5. 2019

Accepted/Přijato: 28. 7. 2019

doi: 10.14735/amko2019277

\section{Klíčová slova}

ncRNA spojená s P21 - aktivace poškozením DNA - PANDA - RNA - dlouhé nekódující - karcinomy močového měchýře 


\section{Introduction}

Long non-coding ribonucleic acids (IncRNAs) with sizes of more than $200 \mathrm{nu}$ cleotides constitute the main part of the human transcriptome. Although they do not encode proteins, they participate in multiple biological activities [1,2]. Dysregulation of their expression contributes to conferring malignant phenotypes in diverse tissues [3]. The IncRNA P21 associated ncRNA deoxyribonucleic acid damage activated (PANDA) gene location is near the cyclin-dependent kinase inhibitor $1 \mathrm{~A}(\mathrm{CDKN} 1 \mathrm{~A})$ gene and is transcribed antisense to CDKN1A [4]. The expression of this IncRNA is induced in a p53-dependent fashion following deoxyribonucleic acid (DNA) damage. Its interaction with the transcription factor NF-YA leads to suppression of the expression of pro-apoptotic genes [4]. Furthermore, this IncRNA interacts with scaffold attachment factor $A$ to recruit polycomb repressive complexes and inhibit the expression of senescence-enhancing genes [5]. Peng et al. have reported a lower expression of PANDA in hepatocellular carcinoma samples compared with peri-tumour tissues [6]. However, forced overexpression of this IncRNA has enhanced cell proliferation and tumourigenesis potential both in vitro and in vivo [6]. In the osteosarcoma cell line, PANDA stimulates G1-S transition and increases cell proliferation by suppressing p18 transcription [7]. Zhan et al. have demonstrated up-regulation of this IncRNA in bladder cancer tissue compared with the corresponding adjacent noncancerous tissues (ANCTs) [8]. In addition, they reported positive correlations between PANDA over-expression and higher histological and advanced tumour, node, metastasis (TNM) stage [8]. Based on the inconsistency of data regarding the expression pattern of PANDA in diverse cancer types, we designed the current study to evaluate its expression in bladder cancer tissues, ANCTs and normal bladder tissues.

\section{Materials and Methods \\ Study participants}

In the current study, we recruited 50 patients with histopathologically-defined bladder cancer. Both tumour tissue and ANCTs were excised during bladder surgery. The patients received no prior chemo/radiotherapy. Furthermore, 30 samples were excised from the bladder tissue of corpses to be used as controls. The individuals recruited as controls had no history of urogenital disease or cancer. Permission to use these tissues was obtained from the guardians of the deceased. The study protocol was approved by the ethical committee of the Shahid Beheshti University of Medical Sciences. All the patients signed written informed consent forms.

\section{Assessment of PANDA expression}

Total RNA was extracted from the tissue samples using TRIzol ${ }^{\mathrm{TM}}$ Reagent (Invitrogen, Carlsbad, California, USA). The quality of the RNA was assessed using a Thermo Scientific NanoDrop Spectrophotometer. The RNA purity was assessed by measuring the ratio of absorbance at 260 and $280 \mathrm{~nm}$. Samples with ratios around 1.9 were regarded as acceptable. About $500 \mathrm{ng}$ of RNA was converted to complementary DNA (cDNA) using a High-Capacity cDNA Reverse Transcription Kit (Applied Biosys- tems, USA) according to the manufacturer's instructions. The expression levels of PANDA were compared between tumour tissues, ANCTs and control samples in a Rotor Gene 6000 Real-Time PCR Machine (Corbett, Australia) using a TaqMan ${ }^{\circledR}$ Universal PCR Master Mix (Applied Biosystems, USA). The HPRT1 gene was used as the endogenous control. The PCR programme included a preliminary step at $94^{\circ} \mathrm{C}$ for $10 \mathrm{~min}$, forty cycles of $94^{\circ} \mathrm{C}$ for $20 \mathrm{sec}$ and $60^{\circ} \mathrm{C}$ for $40 \mathrm{sec}$ and a final extension step at $72{ }^{\circ} \mathrm{C}$ for $5 \mathrm{~min}$. The sequences of the primers and probes are shown in Tab. 1.

\section{Statistical analysis}

The transcript levels of PANDA in tumour tissues were compared with ANCTs/controls using REST 2009 software. The significance of the difference in the expression of PANDA between the tumour tissues and the ANCTs/controls was evaluated using a t-test. The association between the clinical data and relative expression of PANDA was evaluated using a Chi-square test. $P$ values of less than 0.05 were considered as significant.

\section{Results}

General information

on the recruited persons

General information on the study participants has been summarised in Tab. 2 .

\section{Relative expression of PANDA}

in bladder cancer tissues,

ANCTs and normal tissues

No significant difference has been detected in PANDA expression either between tumour tissues and ANCTs (expression ratio $1.75, \mathrm{P}=0.11$ ) or between

Tab. 1. The nucleotide sequence of primers and probes.

\begin{tabular}{|c|c|c|c|}
\hline Gene name & Primer and probe sequences & Primer and probe length & Product length \\
\hline \multirow[t]{3}{*}{ HPRT1 } & F: AGCCTAAGATGAGAGTTC & 18 & 88 \\
\hline & R: CACAGAACTAGAACATTGATA & 21 & \\
\hline & FAM -CATCTGGAGTCCTATTGACATCGC-TAMRA & 24 & \\
\hline \multirow[t]{3}{*}{ PANDA } & F: GTTTTCCTGTTCGTCGATTCTGG & 24 & 81 \\
\hline & R: GGAAAGCTGAGAGAGACTTTGAAC & 23 & \\
\hline & FAM- CTGGACCACCTCTGAAGGCAGGCA - TAMRA & 24 & \\
\hline
\end{tabular}


Tab. 2. General information of study participants.

\begin{tabular}{|c|c|c|c|c|}
\hline $\begin{array}{l}\text { Study } \\
\text { Groups }\end{array}$ & $\begin{array}{l}\text { Total } \\
\text { numbers }\end{array}$ & Variables & Values & \\
\hline \multirow[t]{15}{*}{ Patients } & \multirow[t]{15}{*}{50} & $\begin{array}{l}\text { age (mean } \pm S D) \\
\text { age range }\end{array}$ & $\begin{array}{l}61.78 \pm 18.29 \\
29-88\end{array}$ & \\
\hline & & \multirow[t]{2}{*}{ gender } & male & 47 (94\%) \\
\hline & & & female & $3(6 \%)$ \\
\hline & & \multirow[t]{2}{*}{ smoking } & negative & $14(28 \%)$ \\
\hline & & & positive & $36(72 \%)$ \\
\hline & & \multirow[t]{2}{*}{ opium addiction } & negative & $25(50 \%)$ \\
\hline & & & positive & $25(50 \%)$ \\
\hline & & \multirow[t]{2}{*}{ recurrence } & negative & $32(64 \%)$ \\
\hline & & & positive & $18(36 \%)$ \\
\hline & & \multirow[t]{2}{*}{ hematuria } & negative & $39(78 \%)$ \\
\hline & & & positive & $11(22 \%)$ \\
\hline & & \multirow[t]{2}{*}{ cytology } & inconclusive & $18(36 \%)$ \\
\hline & & & positive & $32(64 \%)$ \\
\hline & & \multirow[t]{2}{*}{ grade } & high-grade & $32(64 \%)$ \\
\hline & & & low-grade & $18(36 \%)$ \\
\hline \multirow{4}{*}{$\begin{array}{l}\text { Normal } \\
\text { individuals }\end{array}$} & \multirow[t]{4}{*}{30} & age $($ mean $\pm S D)$ & $71.33 \pm 6.97$ & \\
\hline & & age range & $59-84$ & \\
\hline & & \multirow[t]{2}{*}{ gender } & male & $28(93.3 \%)$ \\
\hline & & & female & $2(6.7 \%)$ \\
\hline
\end{tabular}

SD - standard deviation

tumour tissues and normal tissues (expression ratio 2.72, $\mathrm{P}=0.57$ ) (Graph 1).

\section{Association between relative} expression of PANDA in bladder cancer tissues and tumour features Based on the relative expression of PANDA in each tumour tissue compared with the corresponding ANCT, the patients were categorised into two groups (up-regulated vs. down-regulated). Subsequently, the associations between PANDA expression and clinicopathological features were assessed. The expression level of this IncRNA was not associated with any of the demographic or clinical data of patients or cancer-associated risk factors such as cigarette smoking or opium addiction (Tab. 3).

\section{Discussion}

Bladder cancer is one of the most frequently occurring cancers world- wide [9]. Based on the lack of specific symptoms in the initial phases of bladder cancer evolution, diagnosis of this malignancy is delayed and subsequently the therapeutic options are less effective [10]. The need for identification of diagnostic biomarkers has prompted researchers to evaluate the expression of several genes in the tissues or body fluids of the patients $[11,12]$. LncRNAs are among the putative biomarkers and therapeutic targets for this kind of human malignancy [1].

In the present study, we assessed the expression levels of PANDA in three types of bladder tissues including normal, ANCT and tumour tissues and found no significant difference in its expression between these three sets of samples. This IncRNA has been suggested to be involved in a variety of human disorders including neuroinflammatory and malignant conditions $[6,13]$.

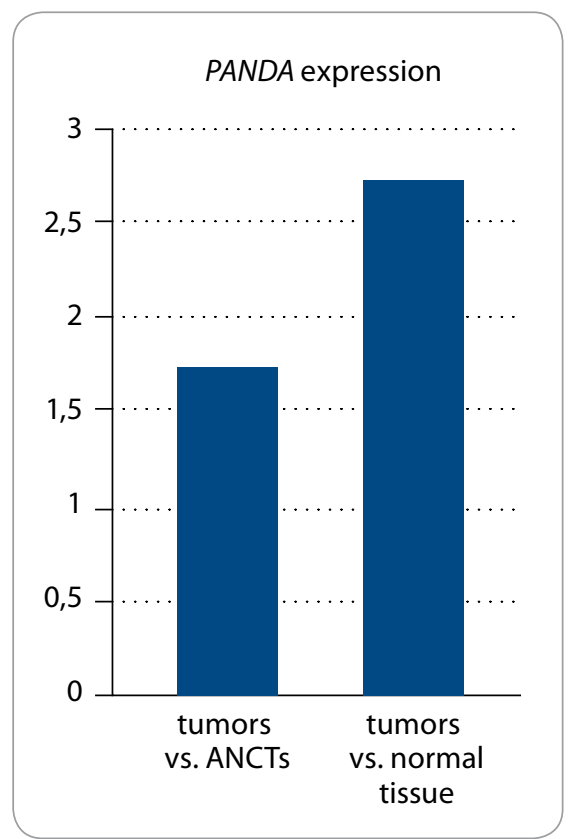

Graph 1. Relative expression of PANDA in bladder cancer tissues, ANCTs compared with normal tissues.

ANCT - adjacent non-cancerous tissues

Moreover, it participates in several cancer-related processes such as DNA damage response, cell proliferation and cell senescence $[4,5]$. Previous studies in bladder cancer cells have revealed that PANDA knock-down suppresses proliferation/migration and stimulates cell apoptosis. Based on these observations, the authors proposed PANDA as a potent tumour biomarker and a therapeutic target in bladder cancer [8]. However, we could not find any difference in the expression of this IncRNA between normal, peri-tumoural and tumour tissues. Moreover, we could not detect any association between the expression levels of this gene and any of the clinical data of the patients. This lack of association further disproves the theory that IncRNA is a tumour biomarker. The inconsistency between our results and those of Zhan et al. [8] might be attributed to ethnicbased factors or differences in environmental risk factors.

We also detected a high prevalence of opium addiction in the patients. Based on the small sample size of the study, we cannot suggest opium addiction as a risk factor for bladder cancer. Previous studies have shown similar roles for both 
Tab. 3. Association between relative expression of PANDA in bladder cancer tissues and tumor features.

\begin{tabular}{|c|c|c|c|}
\hline & $\begin{array}{c}\text { PANDA } \\
\text { up-regulation }\end{array}$ & $\begin{array}{c}\text { PANDA } \\
\text { down-regulation }\end{array}$ & P-value \\
\hline Age & & & 0.27 \\
\hline$<60$ years & $7(50 \%)$ & $7(50 \%)$ & \\
\hline$\geq 60$ years & $24(66.7 \%)$ & $12(33.3 \%)$ & \\
\hline Smoking & & & 0.13 \\
\hline yes & 20) $55.6 \%)$ & $16(44.4 \%)$ & \\
\hline no & $11(78.6 \%)$ & $3(21.4 \%)$ & \\
\hline Opium addiction & & & 0.38 \\
\hline yes & $14(56 \%)$ & $11(44 \%)$ & \\
\hline no & $17(68 \%)$ & $8(32 \%)$ & \\
\hline Recurrence & & & 0.92 \\
\hline positive & $11(61.1 \%)$ & 7 (38.9\%) & \\
\hline negative & $20(62.5 \%)$ & $12(37.5 \%)$ & \\
\hline Hematuria & & & 1 \\
\hline positive & 7 (63.6\%) & $4(36.4 \%)$ & \\
\hline negative & $24(61.5 \%)$ & 15 (38.5\%) & \\
\hline Cytology & & & 0.92 \\
\hline positive & $20(62.5 \%)$ & 12 (37.5\%) & \\
\hline inconclusive & $11(61.1 \%)$ & 7 (38.9\%) & \\
\hline Grade & & & 0.13 \\
\hline high-grade & $14(77.8 \%)$ & $4(22.2 \%)$ & \\
\hline low-grade & 17 (53.1\%) & 15 (46.9\%) & \\
\hline
\end{tabular}

cigarette smoking and opium addiction in the development of bladder cancer [14]. However, we could not find any association between the expression of PANDA and these two risk factors.

The main advantage of the current study was the incorporation of two sets of control samples including normal tissue and ANCT. The former tissue was used to control the intervening effects of tumour cells or tumour microenvi- ronment on the expression of genes in the peri-tumour tissues, while the latter control was applied to adjust the effects of personal risk factors or environmental hazards. However, our study had some limitations regarding sample size and lack of mechanistical studies. Consequently, we propose large-scale studies in different populations to assess the diagnostic power of this IncRNA as a putative biomarker for cancer.

\section{References}

1. Taheri M, Omrani MD, Ghafouri-Fard S. Long noncoding RNA expression in bladder cancer. Biophys Rev Aug 2018; 10(4): 1205-1213. doi: 10.1007/s12551-0170379-y.

2. Dianatpour A, Ghafouri-Fard S. The role of long noncoding RNAs in the repair of DNA double strand breaks. Int J Mol Cell Med 2017; 6(1): 1-12.

3. Taheri M, Omrani MD, Ghafouri-Fard S. Long noncoding RNAs expression in renal cell carcinoma J Biol Today's World 2017; 6(12): 240-247. doi:10.15412/J. JBTW.01061201.

4. Hung T, Wang $Y$, Lin MF et al. Extensive and coordinated transcription of noncoding RNAs within cell-cycle promoters. Nat genet 2011; 43(7): 621-629. doi: 10.1038/ng.848

5. Puvvula PK, Desetty RD, Pineau P et al. Long non-coding RNA PANDA and scaffold-attachment-factor SAFA control senescence entry and exit. Nat Commun 2014; 5 : 5323. doi: 10.1038/ncomms6323.

6. Peng C, Hu W, Weng X et al. Over expression of long non-coding RNA PANDA promotes hepatocellular carcinoma by inhibiting senescence associated inflammatory factor IL8. Sci Rep 2017; 7(1): 4186. doi: 10.1038/s41598017-04045-5.

7. Kotake Y, Goto T, Naemura M et al. Long non-coding RNA PANDA positively regulates proliferation of osteosarcoma cells. Anticancer Res 2017; 37(1): 81-85. doi: 10.21873/anticanres.11292.

8. Zhan YH, Lin JH, Liu YC et al. Up-regulation of long noncoding RNA PANDAR is associated with poor prognosis and promotes tumorigenesis in bladder cancer. J Exp Clin Canc Res 2016; 35(1): 83. doi: 10.1186/s13046-016-03 54-7.

9. Siegel R, Naishadham D, Jemal A. Cancer statistics, 2013. CA Cancer J Clin 2013; 63(1): 11-30. doi: 10.3322/caac. 21166

10. Stenzl A, Cowan NC, De Santis M et al. Treatment of muscle-invasive and metastatic bladder cancer: update of the EAU guidelines. Eur Urol 2011; 59(6): 1009-1018. doi: 10.1016/j.eururo.2011.03.023.

11. Nekoohesh L, Modarressi MH, Mowla SJ et al. Expression profile of miRNAs in urine samples of bladder cancer patients. Biomark Med 2018; 12(12): 1311-1321. doi: 10.2217/bmm-2018-0190.

12. Yazarlou F, Mowla SJ, Oskooei VK et al. Urine exosome gene expression of cancer-testis antigens for prediction of bladder carcinoma. Cancer Manag Res 2018; 10: $5373-$ 5381. doi: 10.2147/CMAR.S180389.

13. Dastmalchi R, Ghafouri-Fard S, Omrani MD et al. Dysregulation of long non-coding RNA profile in peripheral blood of multiple sclerosis patients. Mult Scler Relat Disord 2018; 25: 219-226. doi: 10.1016/j.msard.2018.07. 044

14. Afshari M, Janbabaei G, Bahrami MA et al. Opium and bladder cancer: a systematic review and meta-analysis of the odds ratios for opium use and the risk of bladder cancer. PloS One 2017; 12(6): e0178527. doi: 10.1371/journal. pone.0178527. 